\title{
The road to sustainable creativity: mobile autonomy beyond auto-mobility
}

Pascal Gielen

Abstract: How can artists stay autonomous, and keep their creativity alive in the contemporary society? In this paper is stated that the individual bourgeois model of the artist is not sufficient any more to make autonomous art and to stay creative on the long run. If artists want to stay mobile and autonomous they need to build collective organizational structures, which are called 'traveling caravan'. In the parallel historical shifts between 1970 and 2000 from liberalism to neo-liberalism, from Fordism to post-Fordism and from modern to contemporary art, artists need to build up their own artistic biotope if they need to make their work without governmental interference (subsidizes) and free market solutions. The cooperative can be seen as an interesting model to develop such a 'mobile autonomy'.

Keywords: artistic autonomy, mobility, artistic biotope, post-fordism.

Resumo: O caminho para a criatividade sustentável: autonomia móvel para além da automobilidade - Como os artistas podem permanecer autônomos e manter viva sua criatividade na sociedade contemporânea? Neste artigo afirmamos que o modelo individual do artista burguês não é mais suficiente para se fazer arte autônoma e para ser criativo a longo prazo. Se os artistas desejam permanecer móveis e autônomos, precisam construir estruturas organizacionais coletivas, que são chamadas de "caravanas viajantes". Nas mudanças históricas paralelas entre 1970 e 2000, do liberalismo ao neoliberalismo, do fordismo ao pós-fordismo e da arte moderna para a contemporânea, os artistas precisam construir seu próprio biótopo artístico se quiserem fazer seu trabalho sem interferência governamental (subsídios) e soluções de mercado. O cooperativo pode ser visto como um modelo interessante para desenvolver tal 'autonomia móvel'.

Palavras-chaves: autonomia artística; mobilidade; biótopo artístico; pós-fordismo.

\section{The automobile ideology}

Since its invention and especially its democratization, the automobile has marked our social, political, economic and ecological landscape. The iron capsule on wheels provides 
private individuals with the opportunity to visit any destination at will, at any time of day or night. While the large-scale construction of motorways has irrevocable redrawn the natural landscape over the last century, the car proclaimed an unmistakable message. 'My car, my freedom' mythologizes individual freedom of mobility and autonomy. 'King of the Road' alerts us to ever possible escape routes. While the heavy automobile industry in the United States, even after repeated crises, still strongly influences the political landscape, the car has created its own civil society. The British mobility sociologist John Urry:

Civil society is thus in part a 'civil society of automobility', a civil society of quasiobjects or 'car drivers', and much less of separate human subjects who can be conceived of as autonomous from their machines. People in effect enter the public sphere in their mobility. Automobility is a source of freedom, the 'freedom of the road'. (URRY, 2000, p. 190).

Although the car has gradually been overtaken by airplanes, and by the nanoseconds of the Internet, its creed still stands firmly. The chain of individuality, mobility and self-determination still defines the bourgeois liberal conviction of free private individuals. This is partly because the car simulates a domestic interior, evoking a private atmosphere (these days even with complete home entertainment, including 3D sound systems). One feels, in other words, 'at home' and secure in this metal on wheels, and this is precisely what inspires the sense of freedom. The driver imagines himself as free as in his own private domain while, paradoxically, travelling along public roads. Thus the car enables one to remain private in the public space. And although cars today are subject to strict safety and speed limits, with cameras ever more closely following their trajectory, and in spite of the increasing fixation and - through congestion - vexation of possible routes, drivers still cherish the myth of their individual freedom. Autonomy remains their gospel, even if they know very well that the car is no perpetual motion machine. For while the vehicle seems to be freely cleaving the landscape, its room for manoeuvre is heavily dependent on oil prices, the construction of motorways and a range of government regulations. In short, despite its strong, because compelling illusion of autonomy, the car is in fact a particularly heteronomous being. The possible routes are constantly being curtailed both by changing markets and state infrastructures, while drivers cling to their delusion of being brash libertines in Top Gear. Waving their flag of individual liberty, they choose to ignore oil prices, environmental effects and other regularities. For these self-proclaimed anarchists treasure their shiny aesthetics, powerful engines and devilish speeds. Anyone who denies them the joys of transgression is readily branded a bureaucrat, a 'fascist' even, but more often an annoying 'green guy'. Nothing and nobody shall challenge this brazen automobility, because that would offend driver-ego, yes, even the fundamental right of personal liberty. Where cars take to the public road, private and public freedom, the individual and collective good are constantly being confused. Libertine drivers 
claim their own free will as a political right, while feeling no inclination to contribute to the political constitution that allows them this freedom. Taking the liberty to do their own thing, they decline to take responsibility for the world. Their personal freedom is exempt from collective obligations, not something to freely share with others. Like tax-dodging free-riders who think the road network should be paid for by anyone but themselves, automobilism often encourages irresponsible driving behaviour.

\section{The automobile artist}

After the Belgian Etienne Lenoir built the first internal combustion engine car in 1862, and the German Carl Benz steered his automobile onto the road for the first time in 1885, from 1897 onward the automobility virus also hit the world of the visual arts. Contemporary artists such as Paul Cézanne, Edgar Degas, Edouard Manet and Claude Manet blew up the Academic system with their exhibition at the Musée de Luxembourg. From that moment on, it was no longer the masterpiece that counted, but the individual artist's career and oeuvre (White and White, 1965). This also laid the foundation for a strong belief in the sovereignty of artists over their own work and ideas. The artist as outsider, eccentric, idiosyncratic, whoremongerer, boozer, but also as a model citizen, creative entrepreneur and self-made man, set off to leave an indelible trace in history. The young, nineteenth-century artist breathes the liberal idea of the new citizen. The artist's courage, undaunted appetite for risk and independence transforms into the wet dream of every entrepreneurial citizen (SEIGEL, 1986). The myth of the liberal, autonomous individual finds in the automobile lifestyle of the artist a valuable protagonist. We are all free to expound our private fantasies in the public space. And although, over time, liberalism has given way to neoliberalism, Fordism to post-Fordism and modern art to contemporary art, the individual artist still firmly stands as a prototype. While governments today more than ever encourage entrepreneurship and freelance status, exhibition catalogues of the last two decades proclaim the romance of nomadism. As an artist, you are internationally mobile, or you are not; you stand firmly on your own feet, or you are not. In short, contemporary artists are automobile, or they are not artists, at least not proper artists.

Like every ideology of the last century, the belief in automobility has led to all kinds of denials, negations or repressions. Just like inveterate car drivers, who stuff away into the drawer of their subconscious the congestion and pollution they cause, artists show signs of economic repression, as quite a few sociologists have pointed out in recent decades (see, for example, BOURDIEU, 1977 and 1992). Artists like to boast of their independence from market and state. Even their reliance on social relationships and networks is still a sensitive issue. In the name of artistic freedom, almost any form of commitment will be denied. In this negation, however, artistic and social autonomy are steadily confused. With statements such as 'the social will be the death of you' (DE CORDIER, 2009) 
or claims that they 'have all had to do it on their own', or that 'the academy really taught them nothing', artists uphold the myth of their own automobility. Perhaps it's the bourgeois ideal of individualism that has kindled this confusion between the artistic and the social. Subjecting authenticity and even genius to individual ownership or authorship has led to a great negation of the dependency relationships that each artist - as indeed each ordinary person - is woven into in a society. That is not to say that artists cannot make autonomous art, but rather that they can do this not in spite of, but precisely because of the other. Artistic autonomy, in other words, is possible only when it is collectively supported, and automobility can only exist within an entire network of motorways, fuel suppliers and traffic regulations. This has been termed 'autonomy via heteronomy' (see GIELEN, 2015), with special attention to the linking word 'via', or the road that a vehicle may or must take in order to keep driving. Artistic autonomy presupposes choosing this route over that one, travelling at certain times to certain places and staying there for a certain period, while better giving other - sometimes tempting - destinations a miss. In order to stay automobile, one has to call in at the occasional petrol station or tire centre. In other words, drivers know that their continued driving depends on others, who build the engine and keep it running, maintain the roads and keep destinations accessible.

Meanwhile, research has shown which destinations artists must visit to stay automobile; where they must sojourn at regular times to stay inspired, but also to stay alive. While these places may have remained the same over the decades, the road towards them has become increasingly difficult. The already mentioned transition from liberalism to neoliberalism, Fordism to post-Fordism, modern to contemporary art, went hand in hand with a significant change in the behaviour of economy and politics, of market and state. Petrol stations, tire centres, road builders and traffic regulators are forcing the car onto other roads. Indeed, to stay mobile at all, drivers are forced to build completely different vehicles. In what follows, the necessary renovation works are explained, whilst also clarifying the imperatives behind these construction works.

\section{Road map}

It is well known by now which destinations artists should visit regularly in order to stay autonomous. Various publications and studies have explained how artists must alternate between four petrol stations, or service centres, rather, if they want to stay automobile (see, e.g. GIELEN and LAERMANS, 2004; GIELEN and De BRUYNE, 2009 and 2012; WINKEL, GIELEN and ZWAAN, 2012; GIELEN, 2015). The first destination for most artists was called the 'domestic space'. That means home, the artist's studio, a place to experiment and create in peace, free of any obligations. Here artists can work at their own pace, have their artistic efforts judged in confidence and intimacy by their near and dear ones, friends and lovers. Every artist needs such an oasis of calm and confidence, 
a garage where they can tinker undisturbedly at the engine to get it running at all. Once it does, the emerging talent is advised to speed forthwith to the next destination: the peer space, to have one's artistic first-fruits assessed by experts, and sometimes be forced to fiercely argue the credibility of one's work. Although the artist's career trajectory runs chronologically from domestic domain to peers, both stations remain crucial places to revisit. Every once in a while, all automobile artists must return home or to their studio, at least if they want to survive artistically. But in order to continue driving, they will also have to refuel regularly. Since we all know that petrol and other fuels are pricey stuff, artists should therefore enter a third destination into their GPS navigation system: the market. This domain was defined quite broadly in earlier research: all transactions whereby artistic work is converted into money take place in the market. This would also include government subsidies. It is imperative for artists to find service stations where they can convert their actions, products or activities into cash, which they can then use to refuel and continue driving. In the absence of a substantial inheritance or wealthy patron, artists who want to live from their art will either have to battle for exhibition spaces and subsidies, or simply compete with their fellow artists in the free market. Not everyone enjoys this destination; for the marketplace, like many petrol stations, is often a sterile and uninspiring non-place. And like the intoxicating scent of petrol and exhaust fumes, the smell of money has an equally intoxicating effect, sending many artists into a mad spin. For those really wishing to stay creative, yet another destination calls, that of public recognition. This was termed the civic space, because here the work must be shown in public, and be explained and justified for it to truly incubate as art within society. 'Exposition' in Latin refers to 'making a public argument', or even to 'making an argument public'. Museums, media, even subsidy portfolios are all platforms for artists to proclaim their vision of the world to the world. These public and semi-public places are in fact indispensable for them to truly connect to a culture. But so as not to become too vain, or worse, get stuck in their own ideas, artists, having fled the marketplace, would rather not be condemned to the civic sphere either. To recharge their batteries, it is best for them to return for a short or longer stay to their familiar place of residence. In other words, to ensure their mobility in the long run they must return home now and again, popping out to their peers as well.

It is perhaps the tautology of this story: in order to stay automobile, drivers must stay automobile - in the sense that they must put in at different petrol stations, service centres and resting places to stay on the job (and in the job). Lingering in the same domain for too long will end in artistic standstill. Mobile autonomy: the artist must remain mobile to be at all autonomous. Getting stuck in any one place means to lose one's automobility, i.e. one's autonomy as well as one's artistic mobility. But the moral of the story is also that artists can't do without these pit stops. To keep themselves going they are forever dependent not just on others, but also on a string of service centres. Indeed, no autonomy without heteronomy, i.e. no artistic authenticity and idiosyncrasy without a heterogeneous social network. 
Similarly: no modern and contemporary art without institutions, no individuality without collectivity, no art without culture. Art can be autonomous and the artist remain automobile only if that autonomy is enforced and guaranteed collectively. Yet it is precisely in the transition from liberal to neoliberal politics, Fordist to post-Fordist labour, modern to contemporary art, that these collective guarantees begin to crumble. The GPS device starts acting weird, drivers cannot find their familiar destinations, and if they do, the services offered there are not what they used to be. It is increasingly difficult to stay automobile. But the poor services offered today also make one thing clear: those drivers who thought of their car as a perpetual motion machine are now forever deprived of this illusion. Equally, the artists who feared that the social would mean death, now appreciate all too well that, on the contrary, it means life. This may be called the paradoxical lesson that neoliberalism teaches us. This ideology compels us to go through life as a lone freelancer, to celebrate our free individuality or - oh yes - be more 'autonomous'. But this compelling call steadily reveals its opposite truth: we can never do without the other.

\section{Parallel movements}

It all happened in the same period. During more than two decades, from the 1970s to the 1990s, we were caught up in at least three historical movements. Firstly, primarily in the West, the liberal representative democracy was supplanted by a neoliberal model, i.e. the welfare state by a free market model. This political history is well known: a wide array of public services was privatized, while the venerable statesman-politician of old now emerged as a strategic accountant of a - sometimes inextricably - large corporation. Good arguments and election victories were now solely founded on solid cost-calculating principles, with reason losing out to rationality. Money for education and culture was now called an 'investment in human capital'. Secondly, at the beginning of this same period, car workers in Italian Fiat factories were rising up for dignified working conditions. From 1968, with students joining in, this dignity was translated into respect for authenticity, personal creativity and a demand for flexible or part-time work. In the Eighties, the corporate world embraced these demands, neatly tailoring them to their own needs. The rigid organizational structure of car builder Henry Ford was finally broken. From now on, flexible labour was the norm, preferably on a freelance basis, and a model worker was above all else a creative worker. Post-Fordism was born, in other words. Immaterial labour now ranked at least equal to material labour. Car design got a separate economic value, besides its familiar functionality, notably its displacement capacity. Automobility, in other words, was no longer sufficient in itself. It had to be done with a certain style.

A third shift is seen in the art world. In the 1980s, artists shook off their otherworldliness and started to adopt a star attitude. Trading their tousled hippie outfits for trendy glasses and Armani suits, calling themselves no longer modern, but contemporary artists. 
And admittedly, travelling more by plane than by car. Instead of driving to the local museum, they now flew from biennale to biennale. With the rise of low-cost airlines in the early 1990s, it was not only the artistic jet set that could fly around the globe. In their droves, the (once again) plainly dressed artist-backpackers started to fly from event to event, residency to residency, summer school to summer school... But the flocks of artists and other creatives taking to the air these days should not mislead us. More often than not they still embrace their own automobility, air-hopping individually from place to place to feed their own creativity and bolster their strictly personal careers. As observed elsewhere about these nomadic artists with their alternative looks, outspokenly radical political views and socially engaged artistic actions, these air-hopping art types still remain caught, like most people, in the neoliberal infrastructure, even growing increasingly dependent on it (see e.g. GIELEN, 2015).

Viewing this trend from the perspective of our four petrol stations or service centres, we see how the market steadily increases its domain, even encroaching on and reconfiguring the domestic, peer and civic spaces. From the 1970s, this came to be called the 'commodification of culture', or simply 'commercial art'. From a sociological angle, though, it is more interesting to note how the entire road system is redesigned on free-market principles. Not just by way of commercial intuition, but even more by rationalization. The first thing the marketplace teaches us, is to calculate projects - artistic ones too as well as oneself. In the marketplace one learns to estimate the time needed for a project, and to accurately quantify the costs of the entire trajectory. Racing around in the marketplace implies the ability to assess one's personal risks, i.e. to quantify one's personal qualities. When the market domain expands and begins to 'count' in other spaces, we should take this quite literally. In the domestic domain, among peers and in the civic space as well, professionals are learning how to quantify themselves. More and more, we are becoming quantifying and quantifiable human subjects. Our dashboard displays the remaining mileage before we have to put in at the next petrol station. A calculator even keeps exact track of our fuel economy. We all know how this slows down our automobility. With the market domain growing, our course is increasingly subjected to calculations. This constant measurement encourages moderation - which in turn leads to mediocrity. This is illustrated in the domestic domain, with the Internet penetrating the living room and steering the way to creativity through computer programmes, formats and home entertainment. Children no longer sit before a blank drawing paper, but use iPads and preprogrammed game design to develop their creativity. Talk to any architect, and it is clear how design programmes impact the design process. They tend to tame 'wild creativity' by pre-calculating the risks and technical 'feasibility' of each action. This measured creativity leads to moderation, and ultimately to mediocrity. Among one's peers too, one is taught how to calculate according to the rules of the market. Courses in cultural management, art marketing and artistic entrepreneurship are sneaking 
into the academies. Artistic professionals are partly being replaced by creative entrepreneurs, student contact hours and acquired skills duly ticked off. Thus the educational space often a first peer experience - becomes a calculated space, teaching how to calculate. And finally, in the civic domain too, a lot of calculating is going on. While policymakers anxiously try to balance their budgets, bureaucrats steer towards a rigorous quantification of the impact of the arts; and museums count their visitors, while biennales discount their economic impact on the local hotel, restaurant and catering industry into their budget plans. Calculation is the order of the day now, leaving less and less leeway for free-riders and other renegade drivers.

But we still have Top Gear, deluding us with the romance of the law-defying driver. While the authorities are clearing the corpses off the road, Jeremy Clarkson and his cronies smile on camera as they are booked for speeding. While fine particle emissions settle snugly in our lungs, our steady craving for automobility generates a smog cloud unseen before, which we drive through with open eyes. Witness Richard Florida and his flock of policymakers, conjuring up the vision of the happy creative freelancer, while artists see their artistic autonomy shrink in an ever more precarious and calculated existence. Such is the cynical paradox that these neoliberal times are driving us to. Drivers and artists alike, seeing and knowing that their desire for automobility generates these very disastrous side-effects, stubbornly keep driving. Just like the interior of our car makes us still believe we can allow ourselves the freedom of the private sphere within the public domain, the creative industries and creative cities make it seem as if our creativity has no limits. But just like all drivers know that their iron capsule may also be their coffin, all artists flying from biennale to biennale know that they keep up their automobile romanticism at the cost of their own health and well-being. While drivers keep spouting their emissions into the environment, keeping the car industry alive, the nomadic artists continue to fling their exclusive artefacts into the marketplace, feeding the pre-calculated space of art tourism and other more or less alternative cultural industries. Still, automobility ends once the driver's lungs are saturated with fine particles. Similarly, artistic creativity ceases at the point where the powers of imagination are entirely pre-calculated. In short, there will come a day when the environmental pollution of both driver and individual artist will inevitably hit them in the face like a returning boomerang. When private freedom devours public freedom, when individual interests eat up the collective good, personal autonomy can eventually no longer be enforced. But how long can one continue to function in a system that devours itself?

\section{Crash}

It hardly makes sense to point a moral finger at the private driver or individual artist. The pollution problem finds its cause primarily at the structural, or if you like, the collective 
level. For the car drivers' destinations have been thoroughly transmuted. The individual driver may still choose alternative routes, but the choice is limited to the range offered by GPS or road map. Viewing this map from a bird's eye perspective, it becomes clear that as observed above - domestic space, as well as peer space and civic space have ceded ground to the market. The breaking up of collective defence mechanisms under the pressures of globalization and neoliberalism first enabled this geopolitical shift to occur. Institutions have crumbled in recent decades, their once solid walls and rigid border patrols become porous, allowing a market logic to seep through, and compromising their self-sovereignty (see also GIELEN, 2013). In the domestic domain, for instance, the family as a protective institution and social safety net is losing its strength. The rise in divorces and single-parent families must at least partly be attributed to the mobility and flexibility demands of the postFordist labour market. Both moral and financial partner support are falling away, whereas we know from artists' histories and biographies how crucial this family support can be in starting up the engine and maintaining creative activities. Moving to the peer domain, we see that creative zones, open artists' studios and professional meetings are carefully programmed in pre-calculated creative districts, convention centres and gentrification trajectories. For their part, art academies are focusing on calculating student numbers, grinding out graduates and attuning curricula to the labour market. Education in the peer space presents itself as a precisely calculated, and therefore low-risk investment. In other words, school stops being school. Or in the original Greek sense: a place to spend free time. As collective institutions, polytechnics and universities seem unable to keep market and power outside their walls. They can no longer guarantee their students' 'freedom', not least the freedom to reflect with the necessary distance on this same market and power. In effect, universities are losing their autonomy to determine what is and what is not relevant knowledge. And finally, ever bigger institutional cracks appear in the walls of museums and theatres, but also in public opinion magazines and parliaments. Here too, a quantifying logic of attendance figures, sales, audits and election polls prevails. All this leaves artists still free to drive around, but the destinations seem to become increasingly similar. Where they thought to find the openness of the blank canvas, they now encounter in their studios a preprogrammed creative design, and above all a mailbox staring at them pleadingly. Where they expect a profound and instructive discourse, they are now confronted at school with competing students, and with teachers whose critical comments may have as much to do with content as with envy. 'Can I share my new ideas in confidence, or will they be stolen', the artist wonders, 'as I travel to this residency or that summer school to unveil my fresh thoughts? And is my trip to the museum or my flight to the biennale paid for because I am young, unique and utterly original, or because I am young and sexy, bringing in more ticket sales, or at least higher subsidies?' In short, domestic, peer or civic, all domains have become calculating spaces. The blending of market logic with other logics generates an obscurely hybrid, yet liquid zone where everything begins to look like everything else. The free ride is effectively becoming more like a race track where one shifts gear from one non-place to the next. 
The failure of corporate and institutional defences, protective systems and immunization mechanisms leaves the travelling driver on his own. Yet, this imposed individual autonomy offers little freedom, except to circle around the roaring and highly pollutive race track. The only creative innovation offering any comfort is that of still more and better technology, allowing the driver to negotiate the curves with increasing virtuosity. But these curves never change, and this very technology cuts off the chances of ever truly going around the bend. For both driver and spectator, a spin around the race track is turning into a quite boring, even mind-numbing routine. At every biennale the same art, the same ideas and upcoming trends. The artist already knew: nothing so uninspiring as routine, as always having to take the same route, and nothing so deadly as to work with the same, or safe materials. The rat-race in the late-capitalist market may have its initial, highly competitive allure, but after a few years most drivers can't fail to realize that all they do is drive around in circles. The outcome of this repeated circling is well known: the black hole, the burnout, the mild or major depression with greater or smaller conflicts of conscience, and the very occasional suicidal tendency. At such times, one is overwhelmed by a feeling of loneliness. Automobility: that means travelling around the world in a secure capsule which effectively locks out that world. Better formulated: while imagining ourselves in the public sphere, the car shuts out the world, reducing every experience to an auto-experience. That is, an experience of sameness, and mostly of oneself. Sometimes automobilism narrowly borders on autism.

An expanding market, encroaching on other areas, generates an experience of 'sameness' similar to this auto-experience, even though we find ourselves in completely different territory. It is precisely this exponential expansionism which turns the market itself into a colourless, dull and uninspiring place. The invasion of areas outside the market by the market, in other words, generates a curious feedback - whiplash - from those areas to the market. The market itself loses its colour, causing a free market economy in particular to falter at all levels. Perhaps Karl Marx was right after all when he claimed that capitalism would eventually grind to a halt, and perhaps optimistic leftist social scientists do have a point when they profess these days that 'neoliberalism will be its own gravedigger'. Still, all of this remains conjecture.

What does appear certain, however, is that there is something strange going on with the market and, more broadly, our economy. The by now trusted terrain of production, trade, supply and demand doesn't look so trusted to us any more. The market has certainly ceased to radiate trust, partly on account of this observed feedback from other territories. The saturation of the domestic space by preprogrammed design and entertainment, triggers in us a desire to challenge and manipulate. In the imagined privacy of our domestic space, we think we can get away unseen with a certain level of sneakiness and corruption. Starting with some innocuous illegal downloading, to hacking into computer programmes, up to ever more serious piracy. An innovative economy, after all, thrives on creativity 
as much as on crime. Indeed, it is often a thin line between them. In any case, the presence of games, design programmes and the Internet in the living room has spawned a whole new 'creative class', which from the supposed safety of the living room is gradually undermining free market mechanisms. Whether by innocent children's hands or notorious cyber pirates, the streamlined circuit of the market with its standardized formats is frequently compromised. An army of city councillors, lawyers and bailiffs try their best to enforce copyrights and patents, but it seems difficult to stem the steady stream. Linux and other free-riders play it more officially. Anyone entering the domestic space with numbers and formats, can be sure these will be cracked or manipulated sooner or later. Monstrous codes and formats are bound to be catapulted back with equal force from living room to market space. This will inevitably transmute the free market, despite all its blocking efforts in this battle between cyber heroes and 'the patent crowd'.

A similar feedback is coming from the peers. Teach creatives how to work with formats and calculations, and you get what happened in late 2007. Put the most creative mathematicians together, and they come up with the most complex investment models and incomprehensible - sometimes elusive - derivatives. There is nothing so dangerous as 'artists' at the top of the banking world. Witness how creative banking allowed a financial economy to become detached from a real economy, but not without first derailing the latter. A similar adverse feedback can be observed from the civic domain. Give music producers legislative powers, and you are left with only three majors dominating the pop music industry. When the market logic asserts itself too aggressively, the civic space strikes back with copyrights, patents and especially monopolies. Nothing so crippling for a free competition market as the latter. In short, the effects of the recent stock market crash are much more widespread and especially more complex than is commonly suggested. Their continuing impact is felt not only in the domestic, civic and peer domains. The interweaving of these domains with the market is affecting traditional market mechanisms, shaking the very foundations of the market itself as an institution with its established values of free access and a level playing field. These moves and countermoves open the way for an riotous army of free-riders, some with excessively lucrative aims, others with the most revolutionary intentions, and some with terrorist tendencies. When territorial and institutional boundaries dissolve, a hybrid and liquid jungle shoots up where artists may suddenly be political activists, or propagandists, lucrative speculators or social workers, or all five at once. At the same time, we see politics transform into aesthetics, culture into economics, the welfare sector into a trade of the elderly, and private interests into public interest, or vice versa. On this slippery terrain, the freewheeling car driver threatens to lose control over the wheel. The road surface seems more like an ice rink now, with the solo pilot in constant danger of a physical, financial or mental crash. 


\section{Caravan}

How to escape from the free-rider syndrome? That is the crucial question for the driver on the slippery track. There are those that settle for some roadside assistance: a little therapy here, some counselling there, and on they go on their highly individual route. Like the hybrid car, artists also settle for an individual hybrid existence: spinning their engines in just about all social fields, seeing where the vehicle ends up (Van WINKEL, GIELEN et al., 2012). Others set their hopes on structural road works: the restoration of solid, thickwalled institutions that put the market back in its place. However, it is highly questionable whether such a geopolitical strategy of neatly marking off territories has any sense of reality. Car drivers may well have tasted too much of freedom. Would they let themselves be willingly stopped at the border? Would the artist turned nomad be anchored locally again? Refrain from crossing boundaries to become sedentary again? Join the village idiot to be locked up and ridiculed in a local community? Perhaps artists have equally tasted too much of automobility to settle for a few square metres of manoeuvring space. More crucially, such individual choices seem irrelevant. Artists claiming to go local are fooling themselves and the world. The terrain itself, as we saw, has changed. The local has become global. Fibre optics and wireless link villages to world. Local communities enter the cloud in a global spirit. Reversely, the market has infiltrated the local community. The village was invaded by billboards, and here too Facebook or Netflix couldn't be stopped at the front door. Mechelen on the Maas became Maasmechelen Village, and the world's smallest village, Hum, is offered as a tourist destination on the World Wide Web. Sedentary opposition, in other words, makes little sense when the solid ground under our feet has melted. When the entire earth's surface becomes liquid, a sturdy ark is the only chance of survival.

It is becoming ever clearer: in the given economic-political context, artists have little chance of making it on their own. Refusing to sell their soul on the market, and with less access to subsidies, their last individualistic survival strategies are exhausted. To ensure their mobility and autonomy, they will have to create their own space, construct their own roads. But as we know, road construction requires a huge infrastructural effort, too much for a single individual. Perhaps artists should therefore simply relinquish their cosy bourgeois individualism and abandon their cars, which just get stuck in traffic these days anyway. But public transport is no option either for artists wanting to do their own thing. Buses and trains follow fixed routes, firmly sticking to the beaten track. In short, mobile autonomy can only be attained by finding one's way outside private and public transport, between market and state. But in a hybrid, liquid world, where the public and the private intertwine, where public transport is operated by private companies, which are in turn secured by governments, such a pure interstitial space might well belong to the dreamy realm of unattainable paradises. Artists may have to build their own hybrid vehicles if they want to keep driving. That is to say, their autonomy will ultimately depend on 
their ability to think and act on both an economic, political and artistic level. Better: artists will have to create their own economy and politics. For this they depend on the help of many others, preferably not all of them with artistic ambitions. For once again: autonomy can only be through heteronomy. Only by committing to a heterogeneous group of activists, economists, ecologists, political scientists, sociologists and other 'do-it-yourselfers', well away from the professional art world and well-trodden biennale circuit, can artists carve their own road. Mobile autonomy, in other words, is only feasible when artists commit themselves to a caravan, one that keeps the road safe, yet also collectively determines its direction, and guarantees the autonomous route. Those who want to get out of the current neoliberal constellation must set up their own constitution. And we all know that any individualistic path rejects the 'con' in constitution. The artist will have to find allies, in other words, form gangs, join neotribal groups to find a way out. This means, concretely, that artists are seeking out new modes of transport and organization. This quest is giving rise to an amalgam of experiments. Quite often, perhaps not by coincidence, we witness the resurfacing of the co-operative model. Ever since the mid-nineteenth century, such collectives have been seen to step in where government is absent, the state withdraws or the market is dominated by exploitative rent-seekers and monopolies (CROWE, 2013, p. 81). The co-operative is itself, if course, a hybrid organization where politics and economy, democracy and ownership, but also professional and personal lives constantly intertwine. The co-operative covers all of life, as it were, but perhaps for that very reason it can generate an entirely different life route. This collective organization, which takes capital back into its own hands, formulates a hybrid answer to the hybrid liquid context in which it finds itself. It fights the 'enemy', so to speak, with their own means. Perhaps it is this she-wolf in sheep's clothing, her true identity barely noticed, that will one day lead the herd into a radically different direction. It is the missing feminine role in Top Gear. The woman behind the still predominantly male, because bourgeois artist, who now suddenly starts to lead the caravan. Within the co-operative body, she takes care of all and of her surroundings, and her surroundings and all take care of her.

When we look around nowadays, we may see that there is not just one, but a colourful host of co-operative-like caravans trekking across the world. Their transnational mobility increasingly keeps them out of the grip of states and governments. Their sense of collectivity and solidarity makes them more and more immune to hysterical markets. Or better, the co-operatives create an oasis of 'private time' and enterprise within a madly spinning world. They draw their energy from diversity, singularity, complementarity and commitment, throwing off all forms of bourgeois individualism and possessiveness. It is within these heterogeneous collectives that artists who want to go beyond market and state can recover their singular voice. Only a close-knit travelling community can hope to reclaim and defend this space for singularity today. Artists, therefore, are fully aware that their artistic freedom can only survive as a shared freedom. Artistic autonomy does not coincide with individual discretion and exemption from collective obligations. It is not about freedom of the world, but freedom for the world. 
Pascal Gielen is professor of sociology of art and politics at the Research Center Arts in Society (Groningen University - the Netherlands) and at the Antwerp Research Institute for the Arts (Antwerp University - Belgium). He is editor in-chief of the international book series 'Arts in Society'. His research focuses on the institutional context of the arts and on cultural politics. Gielen has published many books which are translated in English, Korean, Portuguese, Russian, Spanish and Turkish.

p.j.d.gielen@rug.nl

\section{References}

BOURDIEU, P.'La production de la croyance: contribution à une économie des biens symboliques', In: Actes de la recherche en sciences sociales, 13, 1977.

BOURDIEU, P. Les règles de l'art. Genèse et structure du champ littéraire. Paris: Seuil, 1992.

CROWE, D. 'Between the market and the state', in: Harrison, R. (ed.) People over Capital. The Cooperative Alternative to Capitalism. Oxford: New Internationalist Publications Ltd, 2013.

De CORDIER, T. (2009). 'The Social Will Be the Death of You', In: GIELEN, P. and De BRUYNE, P. (eds.) Being an Artist in Post-Fordist Times. Rotterdam: NAi, 2009

GIELEN, P. and LAERMANS, R. Een omgeving voor actuele kunst. Tielt: Lannoo, 2004.

GIELEN, P. and De BRUYNE, P. Being an artist in Post-Fordist Times. Rotterdam: NAi: Rotterdam, 2009a.

GIELEN, P. and De BRUYNE, P. Teaching Art in the Neoliberal Realm. Realism versus Cynicism. Amsterdam: Valiz, 2012.

GIELEN, P. The Murmuring of the Artistic Multitude. Global Art, Politics and Post-Fordism. Amsterdam: Valiz, 2015.

SEIGEL, J. Bohemian Paris: Culture, Politics and the Boundaries of Bourgeois Life, 1830-1930. London: Penguin: 1986.

URRY, J. Sociology beyond Societies. Mobilities for The Twenty-First Century. London \& New York: Routledge, 2000.

WHITE, H.C. and WHITE, C.A. Canvases and Careers. Institutional Change in the French Painting World. Chicago and London: The University of Chicago Press, 1965.

WINKEL (van) C., GIELEN, P. and ZWAAN, K. De hybride kunstenaar. De organisatie van de artistieke praktijk in het post-industriële tijdperk. Avans: Den Bosch, 2012. 